\title{
Use of simple sequence repeat (SSR) markers for screening blue disease resistance in cotton germplasm exchange
}

\author{
Christopher Faustine ${ }^{1}$, Lucia Vieira Hoffmann ${ }^{2}$, Flora Ismail Tibazarwa ${ }^{3 \star}$ \\ and Everina Lukonge 4 \\ ${ }^{1}$ Department of Life Sciences, The Open University of Tanzania, P.O. Box 23409 Dar es salaam Tanzania. \\ ${ }^{2}$ Embrapa, Rodovia GO-462, km 12, Rural Zone, Santo Antonio de Goias, 75375-000, Brazil. \\ ${ }^{3}$ Tanzania Commission for Science and Technology, Dar es Salaam, P.O Box 4302, Tanzania. \\ ${ }^{4}$ Ukiriguru Agricultural Research Institute, P. O. Box 1433 Mwanza, Tanzania.
}

Received 25 May, 2015; Accepted 13 August, 2015

\begin{abstract}
Blue disease of cotton is an economically important disease of the crop first described from the Central African Republic and spread to other countries. Brazil and other South American countries record crop losses of up to $80 \%$ from infection but no cases of the disease have been reported in Tanzania. Resistance to the disease has been found in African germplasm and transferred to crop cultivars worldwide. Molecular markers linked to blue disease resistance genes have been identified presenting useful tools to identify resistant germplasm. All plants of three Tanzanian cotton cultivars (Gossypium hirsutum L.) UK91, UK08 and UKM08 showed resistance alleles for both the simple sequence repeat (SSR) (DC20027-202 bp) and single nucleotide polymorphisms (SNP) (NG0204310-C) markers but some plants of the Brazilian cultivars (G. hirsutum L.); Ipê, Cedro, Aroeira and Araça lacked resistance alleles. The findings suggest the need for caution to be taken during introduction of exotic germplasm and recognize the value of resistance trait to susceptible Brazilian germplasm when breeding for blue disease resistance.
\end{abstract}

Key words: Cotton blue disease, cotton single nucleotide polymorphisms (SNPs), simple sequence repeat (SSR), resistant alleles in cotton.

\section{INTRODUCTION}

One of the diseases afflicting cotton that is of significant economic importance is cotton blue disease (CBD). CBD was first described in the Central African Republic in 1949 and has since been reported in various regions of
Africa, Asia, and America (Brown, 2001; Correa et al., 2005; Junior et al., 2008). The disease is caused by a virus that belongs to the genus Polerovirus of the family Luteoviridae (Correa et al., 2005), which is transmitted by

${ }^{*}$ Corresponding author. E-mail: ftibazarwa@costech.or.tz.

Abbreviations: SSR, simple sequence repeat; CBD, Cotton blue disease; ECGA, eastern cotton growing area; BYDV, barley yellow dwarf virus; MAS, marker assisted selection; WCGA, western cotton growing area.

Author(s) agree that this article remains permanently open access under the terms of the Creative Commons Attribution License 4.0 International License 
cotton aphids (Aphis gossypii Glover) in a persistent circulative manner (Costa et al., 1997; Santos, 2001). Diseased plants are characterized by leaf rolling, vein yellowing, a moderate to severe stunting due to shortening of internodes, and dark green to bluish coloration of leaves (Brown, 2001). Despite CBD being first described in Africa, no cases of this disease have been reported from Tanzania although the vector (Cotton aphid, Aphis gossypii) has been reported in the Eastern Cotton Growing Area (ECGA) (Kabissa, 1993; Mrosso and Kabissa, 2000). Other members of Luteoviridae family, which affect cereals, have been also reported in Tanzania. Webby et al. (1993) reported the occurrence of Barley Yellow Dwarf Virus (BYDV). Lack of records of blue disease in Tanzania may potentially be due to the absence of the pathogen or presence/ use of resistant germplasm.

In Brazil and other South American countries, the disease poses serious problems for cotton production, capable of significantly reducing productivity of susceptible varieties by up to $80 \%$ if the vectors (cotton aphids) are not properly managed at the early growing stage (Silva et al., 2008). Losses of up to $1,500 \mathrm{~kg}$ per hectare of seed cotton have been reported in Brazil (Freire, 1998), where blue disease is the most important virus and a main concern for the breeding program. Generally, control of CBD is through breeding for resistance and control of cotton aphids using insecticides. Insecticides are expensive, harmful to the environment, and provide seasonal protection unlike use of resistant cultivars that offer a better but less used management option to control the disease (Fang et al., 2009). Therefore, use of resistant germplasm is one of the most economical and reliable methods in managing diseases in cotton. Naturally, occurring resistant parental germplasm is vital for development of resistant crop varieties. Identification of resistant germplasm is done either by screening artificially inoculated plants or screening for known molecular markers closely linked to resistance genes. Artificial inoculation requires controlled environments like greenhouses and growth chambers and can be time-consuming and costly, limiting the application of such phenotype-based resistance selection. The use of molecular markers in Marker Assisted Selection (MAS) unlike artificial inoculation can be performed at any development stage of the plant including on seeds at reasonable cost and with a fast turnaround of information compared to phenotype-based selection (Xiao et al., 2009).

Additionally, germplasm exchange can introduce genotypes susceptible to diseases in a new environment and screening prior to introduction is a challenge in the absence of the pathogen. The use of MAS provides an important tool in identifying resistance in the germplasm to be exchanged. A single gene controls resistance to CBD in cotton (Junior et al., 2008) and molecular markers associated with resistance gene are currently available for use in screening for resistant germplasm (Fang et al., 2009). Fang et al. (2009) conducted a study and identified SSR marker DC20027 that is closely linked to a cotton blue disease resistance locus. Based on the SSR marker they also identified three SNP markers NG0203671, NG0204310, NG0203481, which were tightly linked to the CBD resistance gene. Tanzania has a long standing breeding programme in the Western Cotton Growing Area (WCGA), which started at Ukiriguru in 1939. The focus of the programme has been to develop varieties that are high yielding; diseases and pest resistant; high ginning out turn and exhibit improved fibre properties.

The narrow genetic base of the cotton varieties in Tanzania (Lukonge et al., 2007) necessitates the need to introduce new and more diverse varieties from other countries for improvement. Brazil has a relatively broad genetic base of cotton varieties and a history of variety development by the governmental organizations since 1921 (Freire et al., 2011) including introduction of genetic material from different origins followed by crossing and selection (Gridi-Papp et al., 1991). Some of varieties have outstanding field performance and resistance to some diseases (Cia et al., 2008). This may serve as source of germplasm to improve the genetic base of Tanzanian cotton. Screening such germplasm for resistance to diseases prior to introduction of the same into breeding program is vital. The information on the resistance of Tanzanian cotton varieties to cotton blue disease is lacking and this is one of important diseases in Brazil. This study therefore, endeavored to screen the Tanzanian and Brazilian cotton cultivars (Gossypium hirsutum L.) for presence of markers closely associated with blue disease resistance gene using SSR and SNP markers.

\section{MATERIALS AND METHODS}

\section{The study site}

The growth experiments were setup at Lake Zone Agricultural Research and Development Institute (LZARDI) in the WCGA $02^{\circ} 42^{\prime} \mathrm{S} 33^{\circ} 01^{\prime} \mathrm{E}$, about $30 \mathrm{~km}$ from Mwanza city in Misungwi District, Tanzania. Molecular marker analyses were conducted at Embrapa Rice and Beans (Santo Antonio de Goias, Brazil) and DNA Landmarks, Canada. LZARDI is an Agricultural research institute in Tanzania with the mandate for research on cotton and other crops in the WCGA.

\section{Plant materials}

Seven cotton cultivars (G. hirsutum L.) from Tanzania (UK91, UK08 and UKM08) and Brazil (Ipê, Cedro, Aroeira and Araça) were screened in this study. The Tanzanian cultivars are commercial varieties currently cultivated in the WCGA and were all developed LZARDI. The Brazilian cultivars were developed by Embrapa and are also commercially released varieties. Seeds of the test cultivars were sown in the screen house in a Randomized Complete Block Design at LZARDI. All the plants were tagged immediately after they were established. 
Table 1. Primer sequences.

\begin{tabular}{lll}
\hline Primer & & Sequence \\
\hline \multirow{2}{*}{ DC20027 } & $\begin{array}{l}\text { Forward primer } \\
\text { Reverse primer }\end{array}$ & $\begin{array}{l}\text { AATAAACCCTTCAGACAACAG } \\
\text { CTACCTAGTTTTGCATTATG }\end{array}$ \\
\multirow{2}{*}{ NG0204310 } & $\begin{array}{l}\text { Forward primer } \\
\text { Reverse primer }\end{array}$ & $\begin{array}{l}\text { CCCCTGTTTACGAGGCTATCTATTC } \\
\text { GGTTTGGCCCAGTGACTAGAAG }\end{array}$ \\
\hline
\end{tabular}

Table 2. Proportions of plants with markers linked to Cbd resistance gene.

\begin{tabular}{lcc}
\hline Variety & $\begin{array}{c}\text { \% of samples with resistance allele at } \\
\text { DC20027 locus }\end{array}$ & $\begin{array}{c}\text { \% of samples with resistance allele at } \\
\text { NG0204310 locus }\end{array}$ \\
\hline UK91 & 100 & 100 \\
UKM08 & 100 & 100 \\
UK08 & 100 & 100 \\
Araça & 91 & 91 \\
Cedro & 91 & 91 \\
Aroeira & 83 & 83 \\
Ipê & 75 & 75 \\
\hline
\end{tabular}

\section{Leaf sampling for DNA isolation}

Tissues for DNA isolation were obtained from young leaves of individually tagged Tanzanian and Brazilian cotton plants grown in the field three weeks after germination. Sampling was done by punching two discs of the same leaf into a single well of a 96-well plate. Five grams of silica gel were used to dry samples in the plate and replacement was made every till when the samples were satisfactorily dry. Seventeen (17) plants were sampled from each variety.

\section{DNA isolation and quantification}

For the SNP marker NG0204310, DNA isolation was performed using the DNA Landmarks' standard micro-extraction protocol at DNA Landmarks, Canada. DNA concentrations were measured using Hoechst dye and the quality of the DNA samples was checked on a $0.8 \%$ agarose gel (1 column per plate) prior to SNPs analyses. For the SSR marker DC20027, DNA isolation was done at Embrapa, Brazil. Briefly, $0.2 \mathrm{~g}$ of plant material was ground in mortar and pestle under liquid nitrogen to fine powder then added to preheated extraction buffer and mixed thoroughly. The extract was incubated at $65^{\circ} \mathrm{C}$ for $1 \mathrm{~h}$, and mixed in every 20 min then cooled for $5 \mathrm{~min}$ and chloroform: isoamyl alcohol (24:1) mixture was added and vortexed for $30 \mathrm{~min}$ before centrifuging for $20 \mathrm{~min}$ at $3000 \times g$. The supernatant was then transferred to a fresh tube and same volume of ice-cold isopropanol added and tubes inverted several times. The tubes were then centrifuged for $30 \mathrm{~min}$ at $3000 \times$ $g$. The pellet was washed with $70 \%$ ethanol, dried and dissolved in $1 \times$ TE buffer. DNA concentration was checked using Nanodrop 2000 (Thermo Scientific, USA) then diluted to $10 \mathrm{ng} / \mu \mathrm{L}$ for PCR amplification.

\section{SNP genotyping}

The SNP genotyping and analysis using the markers NG0204310 was carried out using the Sequenom Mass ARRAY® Typer 4.0 software.

\section{SSR Amplification and scoring}

SSR amplification for the marker DC20027 was done at Embrapa. The PCR mixture $(5 \mu \mathrm{l})$ contained $1 \mu \mathrm{l}$ template DNA $(10 \mathrm{ng} / \mu \mathrm{l}), 2.5$ $\mu$ of $2 \times$ QIAGEN PCR Master Mix (HotStarTaq DNA Polymerase, PCR Buffer and dNTP Mix), $0.5 \mu \mathrm{l}$ of $\mathrm{Q}$ solution (PCR additive that facilitates amplification of difficult templates by modifying the melting behavior of DNA), $0.06 \mu \mathrm{l}$ of forward and reverse primers and $0.88 \mu \mathrm{l}$ of sterile double distilled water (Table 1). Amplification was performed in $0.2 \mathrm{ml}$ (each tube) thin walled PCR plates (96 tubes / plate) in a thermal cycler (Applied Biosystems). The DNA was first activated at $95^{\circ} \mathrm{C}$ for $15 \mathrm{~min}$ and amplification temperatures were: denaturation $94^{\circ} \mathrm{C}$ for $1 \mathrm{~min}$ and $30 \mathrm{~s}$, then annealing at $55^{\circ} \mathrm{C}$ for $1 \mathrm{~min}$ followed by extension at $72^{\circ} \mathrm{C}$ for $1 \mathrm{~min}$, for 40 cycles. The PCR products were genotyped using Genetic Analyzer (Applied Biosystems Inc.) and scoring was done using GeneMapper software. Deltapal was included as positive control (resistant) and FM966 as negative control (susceptible).

\section{RESULTS}

Deltapal which is known to be resistant and was used as positive control had 202 bp at SSR DC20027 and C at NG0204310 while FM966 (susceptible) had 200 bp on SSR DC20027 and T at NG0204310 locus. All samples for varieties from Tanzania (UK91, UK08 and UKM08) showed resistance alleles for both SSR (DC20027202bp) and SNP (NG0204310-C) markers. Some of plants of the cultivars from Brazil, which is, Ipê, Cedro, Aroeira and Araça lacked resistance alleles, as shown in Table 2. The two markers presented coincident results, that is, the potentially susceptible plants lacked both the 
SSR and the SNP linked to the locus, and the potentially resistant plants showed the SSR and the SNP linked to it.

\section{DISCUSSION}

Cotton breeding in Tanzania is challenged by reduced genetic diversity of $G$. hirsutum as observed among the 26 studied varieties by Lukonge et al. (2007). This is currently being addressed by studying the potential consequences of introduction of more diverse cultivated cotton varieties from other countries to enable improvement of the available germplasm. CBD caused by Cotton leaf roll dwarf virus of the genus Polerovirus of the family Luteoviridae is a serious problem in cotton growing countries in the world especially in South America. Brazil reported yield losses up to $80 \%$ in susceptible varieties (Silva et al., 2008). CBD spreads very fast and is difficult to control. In this study, all plants of the Tanzanian cultivars tested indicated the presence of alleles linked to the CBD resistance gene at SSR DC20027 and SNP NG0204310 loci. Screened Brazilian cultivars on the other hand registered a mixture of both marker alleles present in resistant and susceptible plants. These findings are important to the cotton-breeding programme in Tanzania as they provide the baseline information on the presence of resistance markers in local germplasm and the efforts to sustain this trait should be considered. The fact that all plants that had resistance marker on SSR DC20027 locus confirmed the presence of the same trait on the SNP NG0204310 locus and the presence of markers linked to resistance gene in all tested plants of the Tanzanian cultivars as observed in this study indicates their potentiality for such trait which could be confirmed by artificial inoculation.

The results from this study conform to prior information given Lukonge (Pers. Comm.) on the lack of reported cases of the CBD in the WCGA in the recent years. The results further suggest the possibility of using this valuable germplasm in breeding for CBD resistance in areas where the disease causes significant losses once confirmation on their resistance is done. Thus, screening of exotic germplasm for CBD should always be done before incorporation of exotic germplasm into local breeding programmes. However, it is yet to be established whether absence of cases of the disease is due to absence of pathogen or resistant germplasm. It is believed that CBD resistant varieties across the world have been developed through crosses with African germplasm. For instance, in 1980s, South American countries particularly Brazil and Argentina introduced the African germplasm to combat this disease (Royo et al., 2003). It is thus likely that the partial resistance traits observed in the Brazilian germplasm in this study originated from African germplasm. Findings of this study further complement the observation made by Fang et al. (2009) who screened different cotton varieties for the presence of markers linked to CBD and found that most of varieties from Africa and South America had the markers for resistance.

The observed scenario that Brazilian germplasm had mixture of both resistance markers and susceptible ones to the disease suggests the need to make such populations homozygous for the trait. This could be possible through use of marker assisted selection. Individual plants of Brazilian cultivars that presented resistance markers at both loci can however be considered for multiplication and introduction into local breeding program to improve the local cotton production. Basing on the results of this study, it can be concluded that there is partial resistance in the population of Brazilian cultivars screened and so selection for breeding using such cultivars should consider using plants with resistance trait to CBD and marker assisted selection could be a useful tool to achieve such selection.

\section{Conflict of interests}

The authors did not declare any conflict of interest.

\section{ACKNOWLEDGEMENT}

The authors wish to thank LZARDI-Ukiruguru and the EMBRAPA centre for Rice and Beans for the technical assistance and provision of experimental space, the University of Dar es Salaam, botany department for the guidance on screening mechanisms. This work is part of a grant from the Africa - Brazil Agricultural Innovation Marketplace, project ID 214.

\section{REFERENCES}

Brown JK (2001). Cotton blue disease. In: Kirkpatrick TL, Rothrock CS (eds) Compedium of cotton diseases, 2nd edn. APS Press, St. Paul. pp. 50-51.

Cia E, Fuzatto MG, Kondo JI, Sabino NP, Galbieri R, Lüders RR, Carvalho LH, Ito MF, Erismann NM, Chiavegato EJ, Bolonhezi D, Foltran DE, Kasai FS, Bortoletto N, Gallo PB, Recco PC and Rossetto R (2008). Performance of cotton genotypes in the state of São Paulo: yield, disease resistance and fiber quality. Ciência Rural 38.326-331.

Corrêa RL, Silva TF, Simões-Araújo JL, Barroso PAV, Vida IMS, Vaslin MFS (2005). Molecular characterization of a virus from the family Luteoviridae associated with cotton blue disease. Arch. Virol. 150: 1357-1367.

Costa AS, Juliatti FC, Ruano O (1997). Cotton (Gossypium hirsutum L.): Diseases caused by viruses. In: VALE, F.X.R.; ZAMBOLIM, L. (Ed.). Control of plant diseases: field crops: UFV. pp. 571-582.

Fang D, Xiao J, Canci PC, Cantrell RG (2009). A new SNP haplotype associated with blue disease resistance gene in cotton (Gossypium hirsutum L.). Theor. Appl. Genet. 120:943-953

Freire EC (1998). Blue disease has a solution. Cultivar, Pelotas 1:64-65

Freire EC, Morello CL, Farias FJCF (2011). Cotton breeding and cultivars obtained for the Cerrado In: Freire, E. C. Algodão no Cerrado do Brasil. Abrapa, 2011. Bragantia 43: 405-423.

Gridi-Papp IL, Cia E, Fuzatto MG, Cavaleri PA, Chiavegato EJ, Silva NM, Carvalho LH, Sabino NP, Kondo JI, Sugimori MH, Soave J, Ferraz CAM (1991). Cotton improvement in the state of São Paulo: obtaining the variety IAC 19. Bragantia, Campinas. 50 (2):181-194. 
Junior OP, Schuster I, Pinto RB, Pires E, Belot JL, Silvie P, Chitarra LG, Hoffmann LV, Barroso $P$ (2008). Inheritance of resistance to cotton blue disease. Pesq. Agropec. Bras. 43(5):661-665

Kabissa JCB (1993). Studies on the biology and ecology of Chrysopid (Neuroptera: Chrysopidae) predators of Helicoperva armigera (Hubner) (Lepidoptera: Noctuidae) (Hubner) and Aphis gossypii (Glover) (Homoptera: Aphididae) on cotton, Gossypium hirsutum (L.) in Eastern Tanzania. PhD Thesis, University of Dar es salaam Tanzania.

Lukonge EP, Herselman L, Labuschagne MT (2007). Genetic diversity of Tanzanian cotton (G.hirsutum L.) revealed by AFLP analysis. Afr. Crop Sci. Conf. Proc. 8:773-776.

Mrosso FP, Kabisa JCB (2000). Evaluation of Betacyfluthrin (Bulldog) $2.5 \%$ against Helicoverpa armigera, (Lepidoptera: Noctuidae) (Hubner) and cotton Aphid, Aphis gossypii (Homoptera: Aphididae) (Glover) on cotton in Eastern Tanzania. Trop. Pestic. Bull. 1:7-9.

Royo OM, Erazzu L, Bonacic I, Poisson J, Montenegro A (2003). Screening of cotton germplasm for "blue disease" under natural field infestation. In: Swanepoel A (ed) Proceedings of the world cotton research conference-3, Cape Town, South Africa. Agricultural Research Council-Institute for Industrial Crops (Pub-lisher).pp. 305316
Santos WJ (2001). Identification, biology, sampling and control of cotton pests. In: EMBRAPA. Cotton: production technology. Embrapa Agropecuaria Oeste. pp.181-226.

Silva TF, Corrêa RL, Castilho Y, Silvie P, Bélot JL, Vaslin MFS (2008). Widespread distribution and a new recombinant species of Brazilian virus associated with cotton blue disease. J. Virol. 5:123.

Webby GN, Lister RM, Burnett PA (1993). The occurrence of Barley yellow dwarf viruses in CIMMYT bread wheat nurseries and associated cereal crops during 1988-1990. Appl. Biol. 123: 63-74.

Xiao J, Wu K, Fang DD, Stelly DM, Yu J, Cantrell RG (2009). New SSR markers for use in cotton (Gossypium hirsutum) improvement. J. Cotton Sci. 13:75-157. 